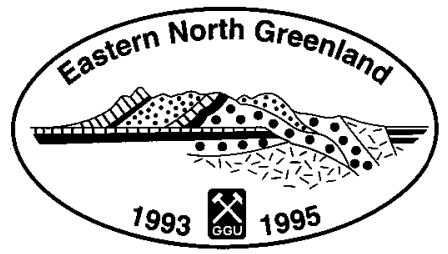

\title{
Conclusion of the 1:500 000 field mapping in eastern North Greenland
}

The third and last field season of the mapping project in eastern North Greenland (1993-95) was completed with full accomplishment of all geoscientific goals. The programme included producing a general overview of the onshore geology of the region between Jøkelbugten and Kronprins Christian Land $\left(78^{\circ}-81^{\circ} \mathrm{N}\right)$ aiming at production of a 1:500 000 geological map sheet. The map (sheet 9 of the Survey's 1:500 000 Greenland series) will cover the last remaining area to be compiled at this scale in North and North-East Greenland. Field work was initiated in 1993 with a limited programme (Henriksen, 1994) and continued with a major field campaign in 1994 (Henriksen, 1995). The planning of the field work in 1995 was carried out as in 1993 and 1994 by the Geological Survey of Greenland (GGU), but following the merger of GGU with the Geological Survey of Denmark (DGU) on 1 June 1995, the field work itself was completed under the auspices of the new institute - the Geological Survey of Denmark and Greenland (GEUS).

In addition to establishing a general overview of the regional geology the project aimed at obtaining an evaluation of the economic geological potential of the region, in respect to both minerals and hydrocarbons (Stemmerik $e t$ al., this report). The field activities co-ordinated by GEUS also included two glaciological projects, one in co-operation with the Alfred Wegener Institute (AWI), Bremerhaven, and the second (Hans Tausen Iskappe project) based on special funding from the Nordic Council of Ministers (Thomsen et al., this report). GEUS was responsible for the logistical organisation of the field work on behalf of all groups. Logistic support was also given to three two-man teams of botanists, whose participation was organised via the Danish Polar Center (DPC).

The field work in 1995 was carried out during a twomonth field season from late June to late August with participation of a total of 46 persons, including 27 geologists and 7 glaciologists. The work was supported by two helicopters and a small fixed wing Twin Otter aircraft, which operated from a tent base camp at Centrum $\$ \varnothing$, south-west Kronprins Christian Land, the site also used in 1993 and 1994. In addition, the military outpost Station Nord was used as a logistic backup point and for transit during mobilisation and demobilisation.

\section{Regional geological studies}

Eastern North Greenland and North-East Greenland comprise rock complexes which reflect a geological development extending over 2000 million years; the oldest units are Early Proterozoic basement gneisses preserved within the Caledonian fold belt and the youngest Late Tertiary Quaternary glacigenic deposits (Fig. 1). The region is dominated by the northern part of the East Greenland Caledonian fold belt, which encompasses both deep seated and high level rock units and sequences. An extensive Caledonian foreland region west of the fold belt comprises unfolded Middle Proterozoic to Lower Palaeozoic successions of sedimentary and volcanic rocks. Post-Caledonian sediments referred to as the Wandel Sea Basin include a sequence of Carboniferous - Tertiary sediments deposited in a series of sub-basins during continental break-up. These sediments are now found in the relatively low-lying coastal regions of eastern North Greenland, east of the up to $1800 \mathrm{~m}$ high alpine peaks of the Caledonian fold belt. The latter includes reactivated Lower Proterozoic crystalline basement rocks as well as folded and metamorphosed representatives of Middle and Upper Proterozoic sedimentary sequences and less disturbed parautochthonous Lower Palaeozoic sediments (Figs 1,2).

The field work in 1995 covered most aspects of the regional geology, and included the following main projects:

- Structure and petrology of the crystalline complexes in the Caledonian fold belt.

- Petrology of eclogites in the Caledonian crystalline complexes; partly financed by the American National Science Foundation.

- Studies of thin-skinned deformation in the western parautocthonous areas of the Caledonian fold belt in Kronprins Christian Land.

- Stratigraphy and structural geology of the Middle Proterozoic Independence Fjord Group in the Caledonian fold belt.

- Stratigraphy and petrology of Middle Proterozoic basic volcanics in the foreland areas and their presumed metamorphic equivalents in the fold belt.

- Sedimentology, stratigraphy and structural geology of 


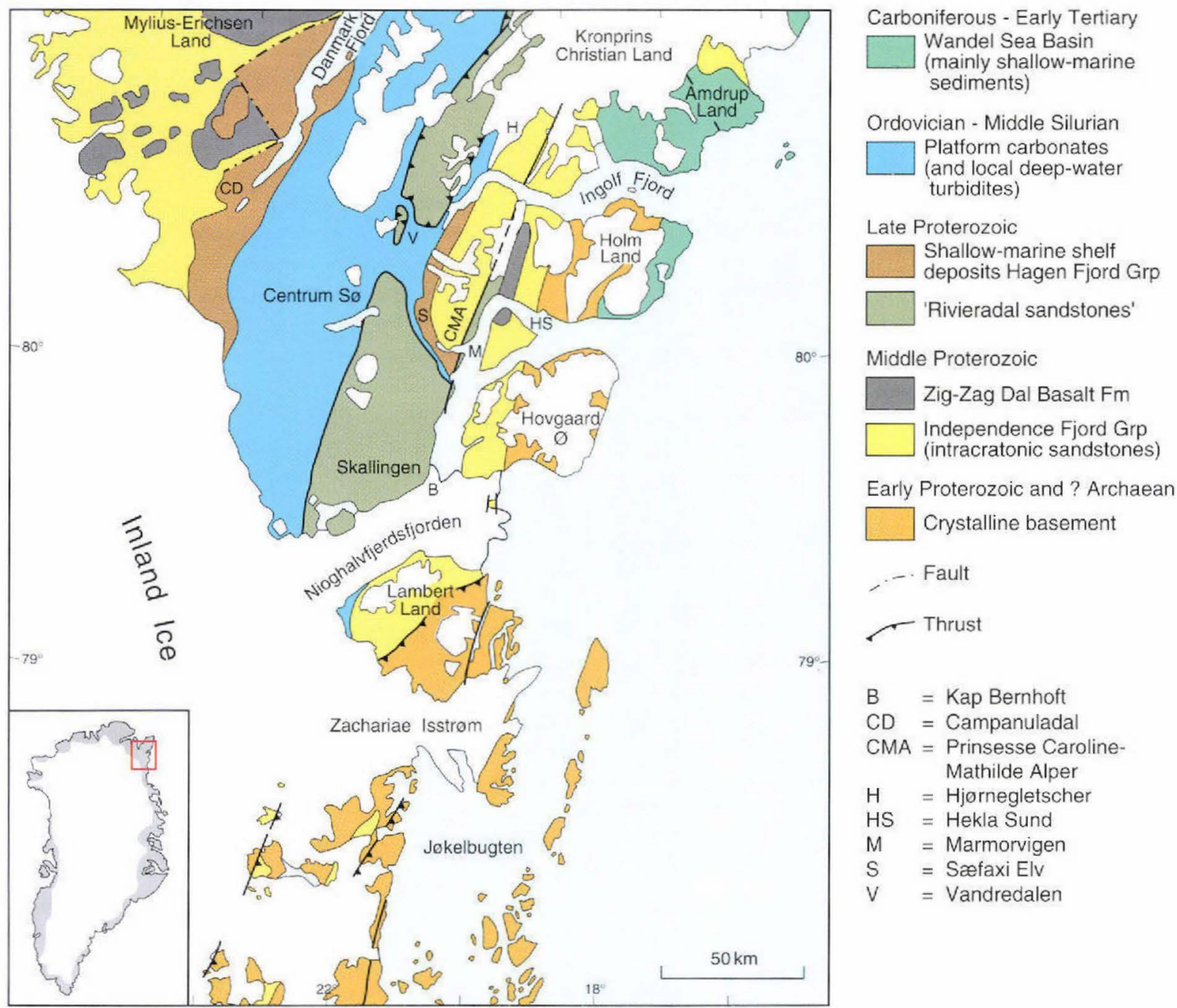

Fig. 1. Simplified geological map of the area covered by the 1:500 000 map Lambert Land $78^{\circ}-81^{\circ} \mathrm{N}$ (sheet no. 9) in North-East and eastern North Greenland. Modified from Jepsen et al. (1994).

the Upper Proterozoic Rivieradal sandstone succession in Kronprins Christian Land; partly financed by the Carlsberg Foundation.

- Biostratigraphy and sedimentology of the Lower Palaeozoic carbonate sediments of Kronprins Christian Land; partly financed by the Carlsberg Foundation.

- Sedimentology and biostratigraphy of the post-Caledonian Upper Palaeozoic - Mesozoic sediments of the Wandel Sea Basin in eastern coastal regions of Kronprins Christian Land; partly financed by the Danish Ministry of Environment and Energy.

Preliminary results of the field work have been summarised by the participating geoscientists in an internal Survey report (Higgins, 1995), which forms the basis for the following presentation. The individuals responsible for the different aspects of this research are listed in the Appendix.
The core of the Caledonian fold belt comprises a variety of crystalline complexes which are widely exposed in the region between $\mathbf{J} \emptyset$ kelbugten and Lambert Land $\left(78^{\circ}-79^{\circ} \mathrm{N}\right)$, and farther north found in poorly exposed outcrops in the coastal areas of Kronprins Christian Land. The crystalline complexes represent segments of the Precambrian Greenland shield (part of the North American Laurentian shield) which have been reactivated during the Caledonian orogeny. Two mapping teams continued their investigations of these rocks in 1995, with one team working in the south and north, while the second team concentrated on studies in the Lambert Land region $\left(79^{\circ} \mathrm{N}\right)$.

The crystalline region in the south is dominated by Early Proterozoic ortho- and paragneisses, overlain by representatives of the Middle Proterozoic Independence Fjord Group (Jepsen et al., 1994). Both units are dissected by abundant basic dykes and sills, which probably correlate 
with the $1250 \mathrm{Ma}$ old Midsommers $\emptyset$ Dolerites of North Greenland (Kalsbeek \& Jepsen, 1983). The crystalline basement rocks have been subjected to an Early Proterozoic orogenic event, and all units have undergone regional deformation and metamorphism to at least amphibolite facies during the Caledonian orogeny. North-west of Jøkelbugten a tectonic window through a thrust sheet of amphibolite facies Lower Proterozoic basement gneisses reveals a broad area of Independence Fjord Group sandstones of lower metamorphic grade. Further important thrusts have been recorded to the west in the nunatak zone. The gneiss complexes are dominated by quartzofeldspathic, polyphase orthogneisses, including metamorphosed diorites, granodiorites, granites, tonalites and trondhjemites. Mafic rocks are abundant, and form pods, lenses, layers and bodies of amphibolite. Anorthositic and eclogitic units are also found in the crystalline complexes. In some areas the gneisses have suffered regional eclogite facies metamorphism, indicating that they were recrystallised at depths of $60-80 \mathrm{~km}$ in the crust. These eclogitic gneisses were subsequently retrogressed and are now generally found in association with amphibolite facies paragneisses. Supracrustal rock units occur as bands and lenses infolded with the crystalline gneisses. They are always strongly deformed, although some metabasites associated with the supracrustal rocks may preserve magmatic textures in their interior parts. Most of the supracrustal rocks are interpreted as representatives of the Middle Proterozoic Independence Fjord Group.

A detailed W-E traverse across the Caledonian fold belt through Lambert Land $\left(c .79^{\circ} 10^{\prime}\right)$ to the islands off the coast to the east has confirmed the results of 1994 studies. The complex Caledonian nappe structure involves interleaving of crystalline basement and Proterozoic - Palaeozoic cover sequences. Four phases of Caledonian ductile deformation have been distinguished, including an early phase of northerly thrusting, followed by westward thrusting and later NNE-SSW shearing. The basement gneisses and overlying supracrustal rocks have similarities with the units found further south in the Jøkelbugten region. The presence of Caledonian intrusive rocks is inferred from lithological and structural relationships; an early foliated basic suite and a later unfoliated acid suite have been distinguished. Future isotopic studies may indicate whether these units are of Caledonian origin or older; the hitherto northernmost Caledonian intrusive rocks have been described from an area $c .400 \mathrm{~km}$ to the south of Lambert Land (Hansen et al., 1994). Prominent anastomosing, NNE-SSW trending ductile shear zones can be traced along the west side of Jøkelbugten and in areas further northwards. The shear zones vary in width from nearly $1 \mathrm{~km}$ down to a few hundred metres, and juxtapose rock units of different crustal levels. They appear to be a continuation of the several hundred kilometre long Storstrømmen shear zone (Strachan \&
Tribe, 1994), an important structural feature throughout the region from Dronning Louise Land $\left(76^{\circ} \mathrm{N}\right)$ northwards.

The detailed study of eclogites and related high pressure rocks in the Jøkelbugten region (Gilotti, 1994) has been continued; the eclogite terrain is now known to extend from south of Dove Bugt $\left(77^{\circ} \mathrm{N}\right)$ to north of latitude $80^{\circ} \mathrm{N}$, a region almost $400 \mathrm{~km}$ from north to south and $130 \mathrm{~km}$ from east to west; The occurrence of eclogites at present outcrop level indicates major geotectonic displacements since their formation at $60-80 \mathrm{~km}$ depth. A Caledonian origin, as indicated by some age determinations (Brueckner \& Gilotti, 1993), implies there has been large scale Caledonian thrusting in the order of several hundred kilometres, or major late Caledonian differential uplift. The study of the eclogitic rocks and their surrounding rock complexes may hold the key to understanding the geotectonic setting of the East Greenland Caledonian fold belt and its relationships with other parts of the Caledonian fold belt around the North Atlantic.

The stratigraphy and structural geology of Middle Proterozoic successions within the Caledonian fold belt were investigated in the Prinsesse Caroline Mathilde Alper region. Extensive outcrops of sandstones correlated with the Middle Proterozoic Independence Fjord Group are present, as well as basalt sequences thought to represent the ZigZag Dal Basalt Formation and abundant dolerite intrusions; these units were involved in Caledonian folding and thrusting, and have undergone low grade metamorphism. A notable find was an up to $400 \mathrm{~m}$ thick basalt sequence within the Independence Fjord Group sandstones. In the foreland all the known Zig-Zag Dal Basalt Formation overlies the Independence Fjord Group sandstones, and the basalts have therefore been considered as entirely younger than the sandstones. Basic sills and dykes occur abundantly within the sandstone sequences in both the foreland and the fold belt, and are all correlated with the 1250 Ma old Midsommers $\emptyset$ Dolerites (Kalsbeek \& Jepsen, 1983).

The Upper Proterozoic 'Rivieradal sandstone' succession is confined to allochthonous Caledonian nappe units (Vandredalen thrust sheet) in the region between Lambert Land $\left(c .79^{\circ} \mathrm{N}\right)$ and northern Kronprins Christian Land $\left(c .81^{\circ} \mathrm{N}\right)$. The succession underlies units of the Hagen Fjord Group, although no precise correlations have been established (Hurst et al., 1985). The study of the sedimentology of these sequences and an analysis of the basin development was initiated in 1994 and continued in 1995. In the western part of the Vandredalen thrust sheet detailed sedimentological studies of key sections were made within the upper part of the 'Rivieradal sandstone'. This part of the succession comprises at least $2000 \mathrm{~m}$ of alternating mudstones and sandstone/conglomerate dominated units. The mudstones and sandstones are mainly outer and inner shelf deposits, while the conglomerates are probably of fluvial 


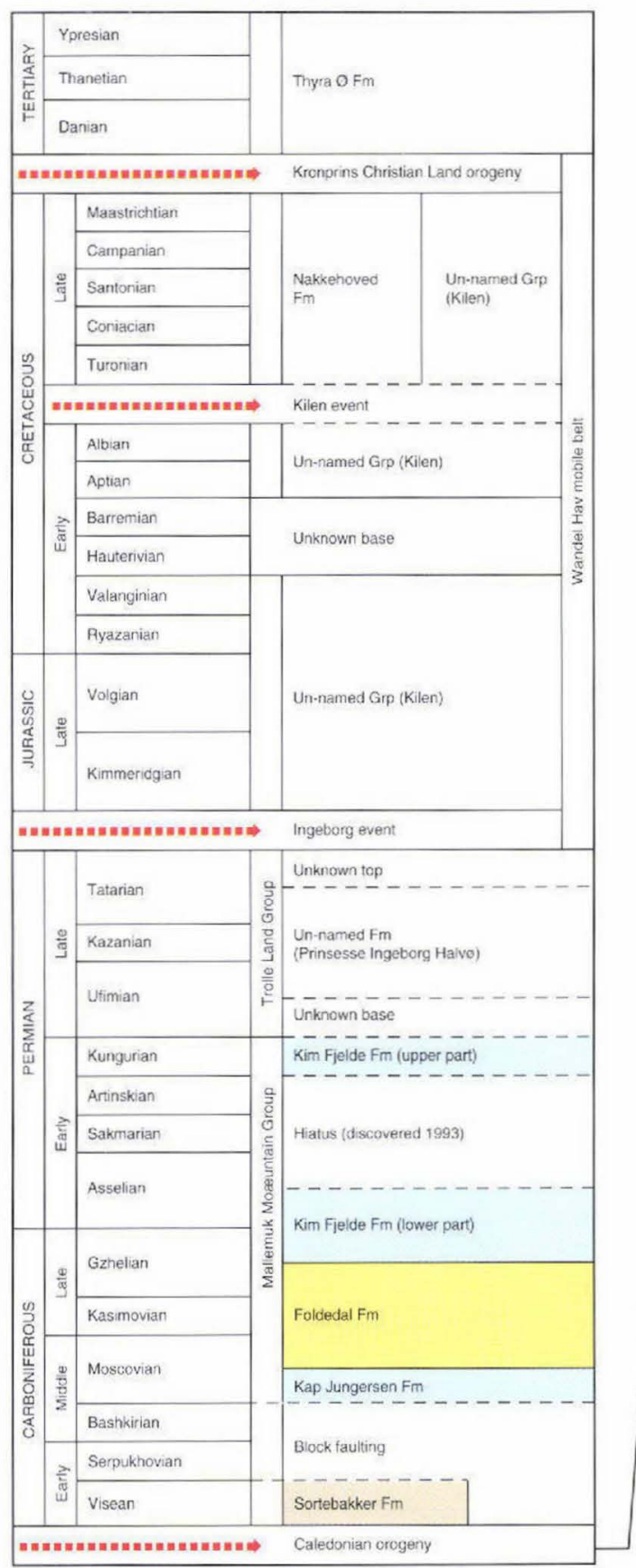

\section{Dominant lithology}

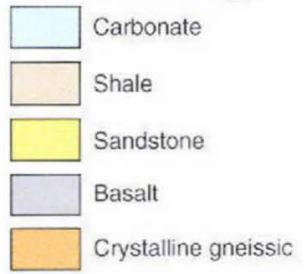

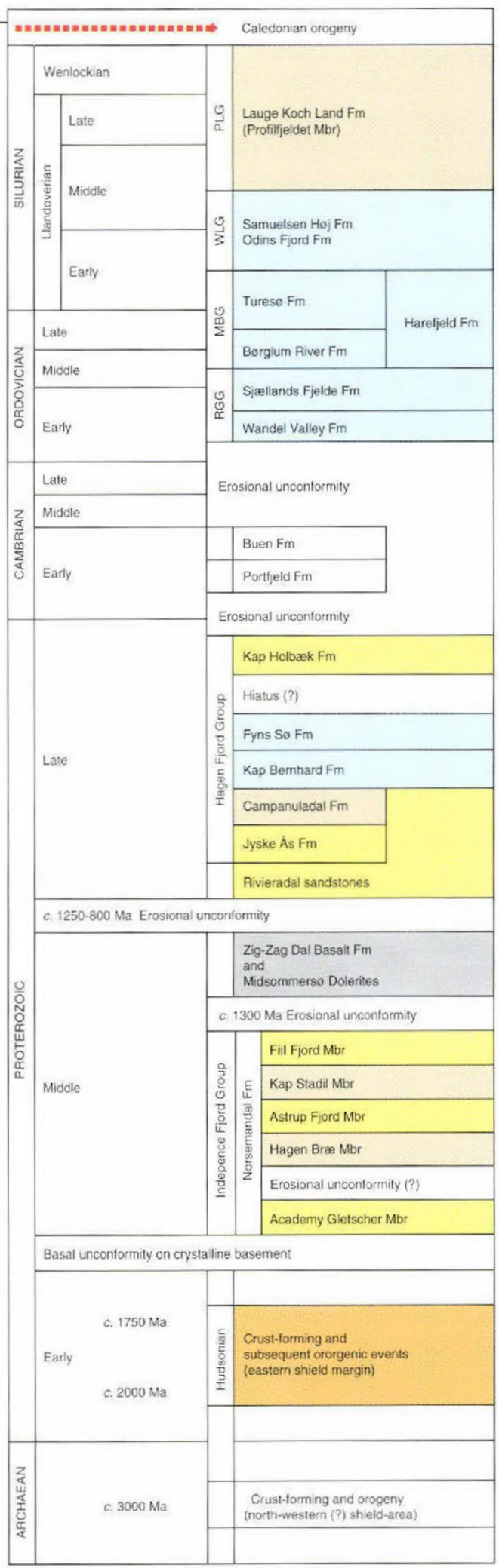

Fig. 2. Scheme showing principal events and lithostratigraphical divisions represented in eastern North Greenland. Colours: units occurring in the 1:500 000 map area $78^{\circ}-81^{\circ} \mathrm{N}$. RGG: Ryder Gletscher Group; MBG: Morris Bugt Group; WLG: Washington Land Group; PLG: Peary Land Group. Modified from Jepsen et al. (1994). 
origin. On the east side of Vandredalen a more than $3000 \mathrm{~m}$ thick sequence of turbiditic mudstone and sandstone at a lower stratigraphical level reflects deep water deposition. The precise age and regional significance of this Upper Proterozoic sequence in North-East Greenland is still open for discussion; systematic collections of material for acritarch studies may help to resolve the age problem.

The studies of the thin-skinned deformation pattern in the parautochthonous areas carried out in 1993 (Jepsen $e t$ al., 1994) and 1994 were continued in 1995; a model based on studies of the Vandredalen thrust sheet indicates a westward displacement in the order of $35-50 \mathrm{~km}$ for this structural unit. Work in 1995 concentrated on an east-west section across the Vandredalen thrust sheet in central Kronprins Christian Land, which will join up with a section through deeper structural levels spectacularly exposed in the cliffs along Ingolf Fjord. These structural studies show a strike parallel division into a series of zones separated by thrusts, with an increasing complexity in the deformation pattern from west to east. The structural style is clearly thin-skinned in the west, characterised by low angle thrusts with ramps and flats and varying fold intensities from place to place. Eastwards there is a transition into a zone with steeper, more deep-seated thrust units, characterised by intense folding (Fig. 3).

In southern Kronprins Christian Land, structural studies along a $50 \mathrm{~km}$ east-west section resulted in a division into three structural domains: a western zone of open upright folds, a central zone of west-verging overturned close folds, and an eastern zone of complex overturned folds and thrusts. However, only the upper and lower parts of the 'Rivieradal sandstone' succession seem to be represented in this section; a thick central part of the succession known farther north in Rivieradal appears to have been cut out here by thrusting.

The Lower Palaeozoic succession of East Greenland and eastern North Greenland was deposited at the western rim of the proto-Atlantic ocean (Iapetus). In Kronprins Christian Land the sediments comprise a sequence of Ordovician Silurian dolomites, limestones and turbiditic mudstones which outcrop in a parautochthonous moderately to gently folded and thrust zone, west of and underlying the Vandredalen thrust sheet. Investigations in 1995 mainly concerned stratigraphical studies, including systematic collection of material for micropalaeontological studies of conodonts (Rasmussen \& Smith, this report). The lowest part of the sequence in Sæfaxi Elv was found to correspond to known formations of the Ordovician Wandel Valley Formation, and not an allochthonous deep-water Silurian succession as suggested by Hurst \& McKerrow (1985); the Sxfaxi Elv nappe distinguished by Hurst \& McKerrow does not exist (Rasmussen \& Smith, this report). In westernmost Lambert Land units of the Wandel Valley Formation were found to rest unconformably on the Independence Fjord Group, which demonstrates that the progressive overstep of the Early Ordovician from west to east across North Greenland (Peel \& Smith, 1988) continues southwards into Kronprins Christian Land.

Stratigraphical and structural studies of the post-Caledonian Wandel Sea Basin (Håkansson \& Stemmerik, 1995) were carried out in the outer coastal areas of Holm Land and Amdrup Land. Upper Palaeozoic sediments were the main target, but in addition the Mesozoic and Tertiary sediments in the northernmost part of Kronprins Christian Land were briefly visited.

In Holm Land Lower Carboniferous fluvial sediments were found to rest on Caledonian reworked Precambrian gneisses, and in northern Amdrup Land Upper Carboniferous sediments overlie isoclinally folded Independence Fjord Group rocks.

\section{Economic geology investigations}

The regional mineral resource reconnaissance programme was planned as a follow-up on geochemical anomaly indications resulting from the geochemical reconnaissance programme in 1993 and 1994, and anomalies detected by analytical studies of Landsat satellite images. The 1995 field work confirmed that the Middle Proterozoic Zig-Zag Dal Basalt Formation and parts of the Hagen Fjord Group sandstones have a potential for $\mathrm{Cu}$ mineralisation. In J. C. Christensen Land $\mathrm{Cu}$ mineralisation was found in a $60 \mathrm{~m}$ wide belt over a distance of $800 \mathrm{~m}$ in Hagen Fjord Group sandstones; an association with regional faults and links with the occurrence of $\mathrm{Cu}$ in the Zig-Zag Dal Basalt Formation is suspected. In 1994 surprisingly high Au values were recorded in Silurian carbonates; analytical results of 1995 sample collections from the same area are not yet available. Field observations suggest possible mineralisation could be related to thrust zones and associated karstic features (Carlite-type gold mineralisation). The spectral enhancement of the Landsat TM images indicated a number of anomaly zones with potential Fe-oxide staining or gossans. A number of these discoloured zones were visited, and in most cases were found to be rusty coloured exposures and shear zones without direct indications of mineralisation. The work on refining the enhancement of spectral signatures for various mineralisation indicators is to be continued in the light of the results from the field work.

Petroleum geological investigations were mainly focused in 1995 on the post-Caledonian sequences in the Wandel Sea Basin; studies of the Palaeozoic platform successions are also planned. Samples will be evaluated for thermal maturity, aiming at establishing a basin development model for both the Lower Palaeozoic foreland areas and the postCaledonian Wandel Sea Basin. The conodont studies from 


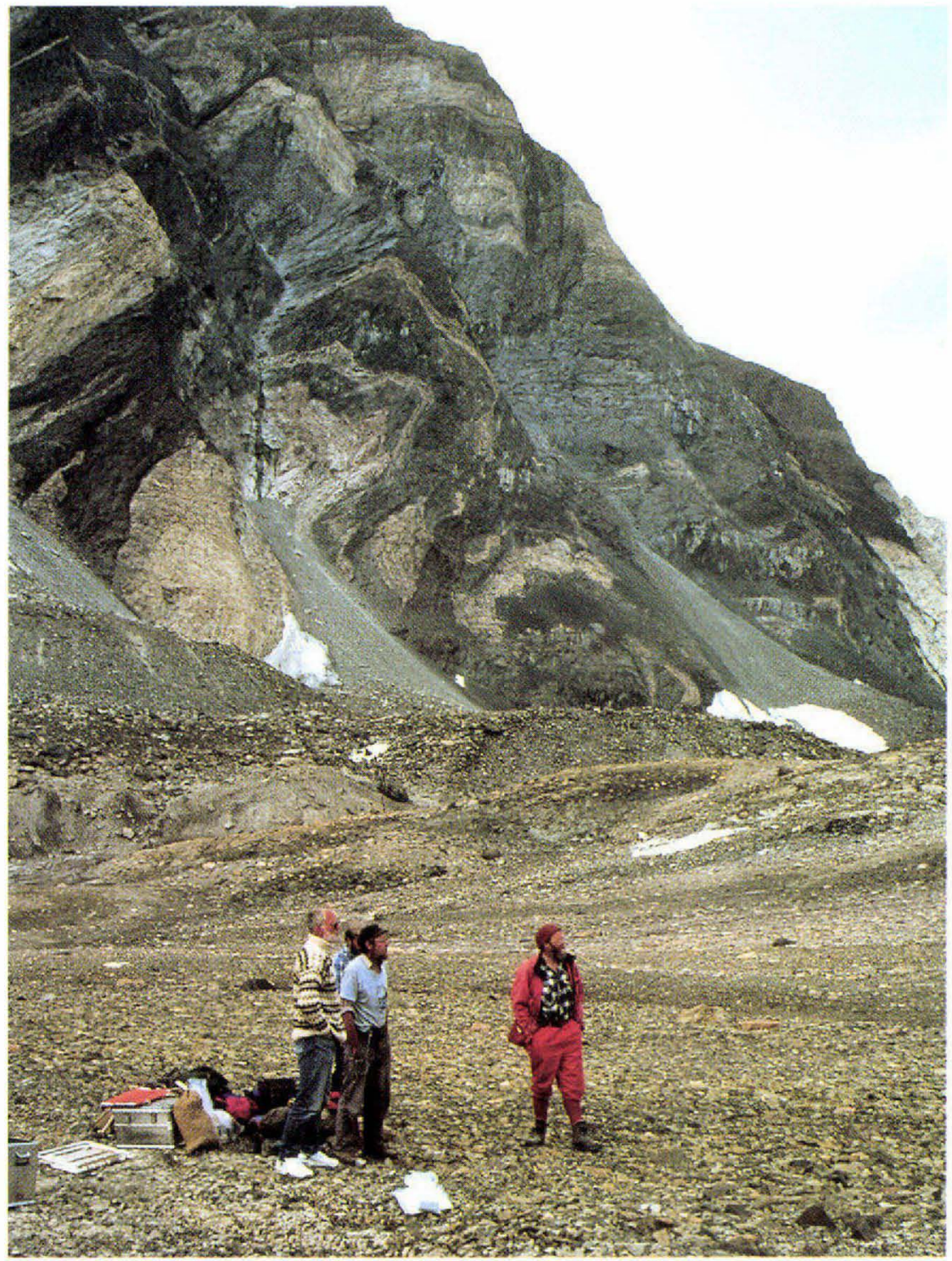

Fig. 3. Intense folding in Proterozoic sandstones and volcanic rocks, intruded by thick basic dykes and sills which are also folded. South side of Ingolf Fjord, Kronprins Christian Land.

the Ordovician - Silurian carbonates will reveal temperature indications (CAI values) and it is planned to undertake thermal maturity analyses and micropalaeontological investigations of the Upper Palaeozoic - Mesozoic and Tertiary units. The interest for oil geological evaluations of onshore outcrops should be viewed in relation to the existence of a very broad continental shelf offshore North-East Greenland which includes thick successions of Upper Palaeozoic Tertiary sediments.

\section{Co-operation with other institutions}

The field work in 1995 involved a continuation of the close logistic and scientific co-operation with the Alfred Wegener Institute for Polar and Marine Research (AWI), Bremerhaven. The glaciological programme on the glacier
Storstrømmen, at the rim of the Inland Ice west of Danmarkshavn $\left(c .77^{\circ} \mathrm{N}\right)$, was continued with establishment of a number of automatic climate stations. Positions of a stake network established in earlier seasons were remeasured by GPS in order to measure ice movement and ablation, and radar reflectors for a SAR (Synthetic Aperture Radar Repeat Track Interferometer) experiment established in 1994 were repositioned. Ice samples were collected for chemical analysis. Additional AWI glaciological investigations were carried out at the rim of the Inland Ice southwest of Centrum Sø in Kronprins Christian Land. Here the main objectives were to remeasure the position of a stake line set out in 1994 in order to determine ice flow velocities and ablation, and to control and retrieve data from two automatic weather stations put up in 1994. Ice samples were collected from a profile line for isotope studies, and samples 
for measurement of dust concentrations, crystal size and chemical analysis were also taken.

Co-operation was also continued with a glaciological group working on Hans Tausen Iskappe, central North Greenland; this programme is funded by the Nordic Council of Ministers and the European Union's Third Framework Programme ENVIRONMENT in co-operation with the Danish Polar Center and the Survey (Thomsen et al., this report). A 'mini-meteorite' study was undertaken on Hans Tausen Iskappe in 1995 by a French scientist, the objectives being to sample extra-terrestrial dust.

Three two-man teams of botanists from universities in Copenhagen and Münster, Germany, coordinated by the Danish Polar Center (DPC), were provided with logistic support by the Survey during a field campaign in the Kronprins Christian Land region. The three teams worked independently, mainly on studies of plants, lichens and mosses, and algae in lakes.

Logistic co-operation was also carried out with the mining company Platinova $\mathrm{A} / \mathrm{S}$, who continued their investigations of the lead-zinc deposit at Citronen Fjord in northern Peary Land. The co-operation included mutual use of helicopters and fixed wing aircraft in the Peary Land region.

\section{Concluding remarks}

The entire region between Jøkelbugten $\left(78^{\circ} \mathrm{N}\right)$ and northern Kronprins Christian Land $\left(81^{\circ} \mathrm{N}\right)$ is now known in sufficient detail to allow compilation of the planned 1:500 000 map. The three years of field work (1993-95) were completed according to plan and a general regional overview of the geology and the economic geological aspects has been obtained. Laboratory investigations continue, and the results will be documented in GEUS bulletins and maps and articles in international publications.

Appendix. The 1995 field parties were:

Crystalline complexes: J. C. Escher \& J. D. Friderichsen (GEUS), K. A. Jones (Oxford Brookes Univ., UK), J. M. Hull (Seattle Central Community College, USA).

Eclogite studies: S. Elvevold (Univ. Troms $\emptyset$, Norway), J. A. Gilotti (Geol. Survey, New York State Museum, USA).

Zig-Zag Dal Basalt Formation (Middle Proterozoic): H. F. Jepsen \& S. A. S. Pedersen (GEUS), L. E. Craig (The Open Univ., Leeds, U. K), B. G. J. Upton (Univ. Edinburgh, UK).

Independence Fjord Group (Middle Proterozoic): S. A. S. Pedersen (GEUS), L. E. Craig (The Open Univ., Leeds, UK), A. G. Leslie (Queen's Univ. Belfast, UK).

'Rivieradal sandstones' (Upper Proterozoic): M. Sønderholm (GEUS), H. Tirsgaard (Mærsk Olie \& Gas, Copenhagen).

Caledonian deformation: A. K. Higgins, H. F. Jepsen \& S. A. S. Pedersen (GEUS), A. G. Leslie (Queen's Univ. Belfast, UK), N. J. Soper (Univ. Sheffield, UK).

Lower Palaeozoic carbonates (and conodonts): J. A. Rasmussen, (GEUS), M. P. Smith (Univ. Birmingham, UK).
Wandel Sea Basin: F. Dahlhoff, S. Piasecki \& L. Stemmerik (GEUS), B. D. Larsen (Aarhus Univ., Denmark).

Mineral resource reconnaissance: $\mathrm{M}$. Lind \& T. Tukiainen (GEUS). Petroleum geological investigations: F. Dahlhoff \& S. Piasecki, (GEUS).

Glaciological investigations (North-East Greenland): C. E. Bøggild (GEUS), F. Jung-Rothenhausler \& H. Oerter (AWI, Bremerhaven, Germany).

Glaciological investigations (Hans Tausen Iskappe): O. B. Olesen \& H. H. Thomsen (GEUS), P. Jonsson (Lund University, Sweden), N. Reeh (DPC, Copenhagen).

Mini-meteorite study: M. Maurette (Univ. Paris, France).

\section{References}

Brueckner, H. K. \& Gilotti, J. A. 1993: Preliminary age constraints on the timing of eclogite facies metamorphism, North-East Greenland Caledonides. Geol. Soc. Amer. Abstracts with Programs 25, 340 only.

Gilotti, J.A. 1994: Eclogites and related high-pressure rocks from North-East Greenland. Rapp. Grønlands geol. Unders. 162, 77-90.

Håkansson, E. \& Stemmerik, L. 1995: Wandel Sea Basin: basin analysis - a summary. Rapp. Grønlands geol. Unders. 165 , $42-48$.

Hansen, B. T., Henriksen, N. \& Kalsbeek, F. 1994: Age and origin of Caledonian granites in the Greandjean Fjord - Bessel Fjord region $\left(76^{\circ}-76^{\circ} \mathrm{N}\right)$. Rapp. Gronlands geol. Unders. 162, 139-151.

Henriksen, N. 1994: Eastern North Greenland 1993-1995 - a new 1:500 000 mapping project. Rapp. Grønlands geol. Unders. 160, 47-51.

Henriksen, N. 1995: Eastern North Greenland, the 1:500 000 mapping project. Rapp. Grønlands geol. Unders. 165, 53-58.

Higgins, A. K. (ed.) 1995: Express Report. Eastern North Greenland and North-East Greenland 1995. Unpubl. internal report, Grønlands geol. Unders., 171 pp.

Hurst, J. M. \& McKerrow, W. S. 1985: Origin of the Caledonian nappes of eastern North Greenland. In Gee, D. G. \& Sturt, B. A. (ed.) The Caledonide Orogen: Scandinavia and related areas, 1065-1068. London: Wiley and Sons.

Hurst, J. M., McKerrow, W. S., Soper, N. J. \& Surlyk, F. 1985: The relationship between Caledonian nappe tectonics and Silurian turbidite deposition in North Greenland. J. geol. Soc. Lond. 140, 123-132.

Jepsen, H. F., Escher, J. C., Friderichsen, J. D. \& Higgins, A. K. 1994: The geology of the north-eastern corner of Greenland photogeological studies and 1993 field work. Rapp. Gronlands geol. Unders. 161, 21-33.

Kalsbeek, F. \& Jepsen, H. F. 1983: The Midsommers $\varnothing$ Dolerites and associated intrusions in the Proterozoic platform of eastern North Greenland study of the interaction between intrusive basic magmas and sialic crust. J. Petrol. 25, 605-634.

Peel, J. S. \& Smith, M. P. 1988: The Wandel Valley Formation (Early - Middle Ordovician) of North Greenland and its correlatives. Rapp. Grønlands geol. Unders. 137, 61-92.

Strachan, R. A. \& Tribe, I. R. 1994: Structure of the Storstrømmen shear zone, eastern Hertugen af Orléans Land. North-East Greenland. Rapp. Grønlands geol. Unders. 162, 103-112.

N. H., Geological Survey of Denmark and Greenland, Copenhagen 